Floodplain/Wetlands Assessment for the Remediation of the Southeast Drainage near the Weldon Spring Site, Weldon Spring, Missouri

Environmental Assessment Division Argonne National Laboratory

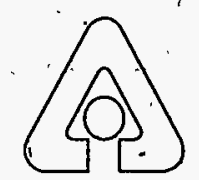

Operated by The University of Chicago, under Contract W-31-109-Eng-38, for the

United States Department of Energy 


\section{Argonne National Laboratory}

Argonne National Laboratory, with facilities in the-states of Illinois and Idaho, is owned by the United States Government, and operated by the University of Chicago under the provisions of a contract with the Department of Energy.

This technical memo is a product of Argonne's Environmental Assessment Division (EAD). For information on the division's scientific and engineering activities, contact:

Director, Environmental Assessment Division

Arg̀onne National Laboratorý

Argonne, llinois 60439-4815

Telephone (630) 252-3107

Presented in this technical memo are preliminary results of ongoing work or work. that is more limited in scope and depth than that described in formal reports issued by the EAD.

Publishing support services were provided by Argonne's Information" and Publishing Division (for more information, see IPD's homé paǵe: http://www.ipd.anl.gov/).

\section{Disclaimer.}

This report wás prepared as an äccount of work sponsored by an agency of, - the United States Government. Neither the United States Government nor

any agency thereof, nor any of their employees, makes any warranty, express or implied, or assumes any legal liability or responsibility for the accuracy, completeness, or usefulness of any information, apparatus, product, orprocess disclosed, or represents that its use would not infringe privately owned rights. Reference herein to any specific commercial product, process, or service by trade name, trademark, manufacturer, or othèrwise, does not necessarily constitute or imply its endorșement, recommendation, or favoring by the United States Government or any agency thereof. The views and opinions of authors expressed herein do not necessarily state or reflect those of the United States Government or any agency thereof.

Reproduced directly from the best available copy.

Available to DOE and DOE contractors from the Office of Scientific and Technical Information, P.O. Box 62, Oak Ridge; TN 37831; prices available from (423) $576-84.01$.

Available to the public from the National Technical Information Service, U.S. Department of Commerce, 5285 Port Royal Road, 'Springfield, VA 22161. 


\section{Floodplain/Wetlands Assessment for the Remediation of the Southeast Drainage near the Weldon Spring Site, Weldon Spring, Missouri}

by R. Van Lonkhuyzen and S.C.L. Yin

Environmental Assessment Division,

Argonne National Laboratory, 9700 South Cass Avenue, Argonne, Illinois 60439

August 1996

DISTAIBUTION OF THIS COCUMEAT IS UMUMATED

Work sponsored by United States Department of Energy,

Oak Ridge Operations Office, Oak Ridge, Tennessee 
This report is printed on recycled paper. 


\section{DISCLAIMER}

Portions of this document may be illegible in electronic image products. Images are produced from the best available original document. 


\section{CONTENTS}

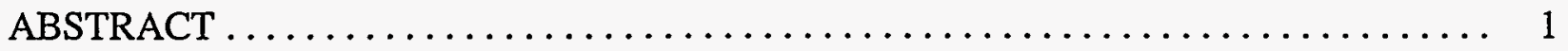

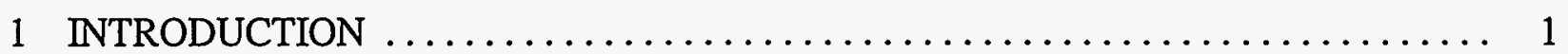

2 DESCRIPTION OF POTENTIAL ALTERNATIVES $\ldots \ldots \ldots \ldots \ldots \ldots \ldots \ldots \ldots$

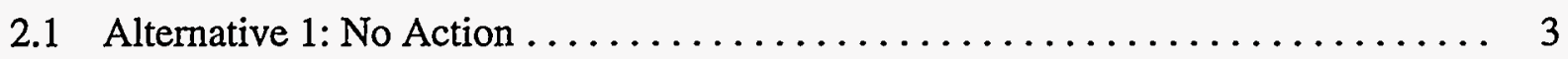

2.2 Alternative 2: Conventional Excavation $\ldots \ldots \ldots \ldots \ldots \ldots \ldots \ldots \ldots \ldots \ldots$

3 DESCRIPTION OF THE FLOODPLAINS AND WETLANDS

OF THE SOUTHEAST DRAINAGE $\ldots \ldots \ldots \ldots \ldots \ldots \ldots \ldots \ldots \ldots \ldots$

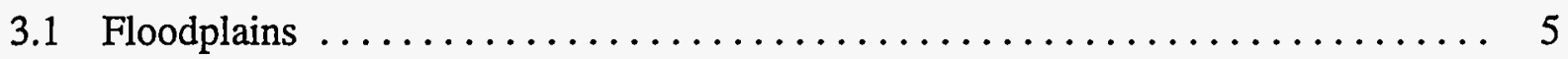

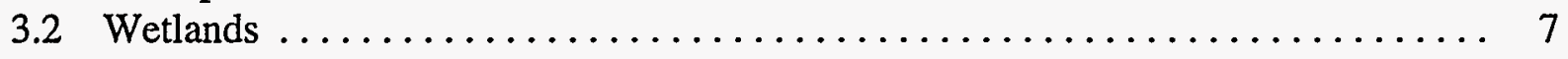

4 POTENTIAL IMPACTS TO FLOODPLAINS AND WETLANDS $\ldots \ldots \ldots \ldots \ldots$

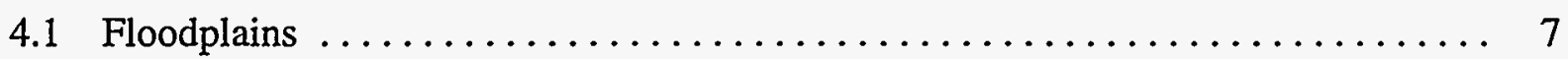

4.1.1 Impacts of the No-Action Alternative $\ldots \ldots \ldots \ldots \ldots \ldots \ldots \ldots \ldots \ldots \ldots \ldots \ldots \ldots$

4.1.2 Impacts of Subalternative $2.1 \ldots \ldots \ldots \ldots \ldots \ldots \ldots \ldots \ldots \ldots \ldots \ldots \ldots$

4.1.3 Impacts of Subalternative $2.2 \ldots \ldots \ldots \ldots \ldots \ldots \ldots \ldots \ldots \ldots \ldots \ldots$

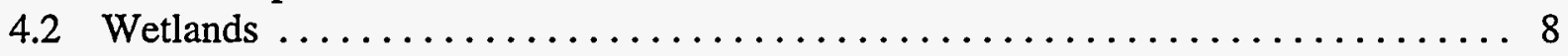

4.2.1 Impacts of the No-Action Alternative $\ldots \ldots \ldots \ldots \ldots \ldots \ldots \ldots \ldots$

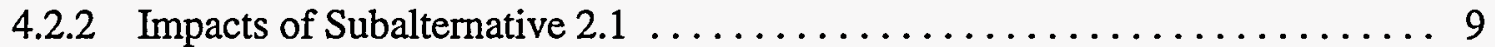

4.2.3 Impacts of Subalternative $2.2 \ldots \ldots \ldots \ldots \ldots \ldots \ldots \ldots \ldots \ldots \ldots$

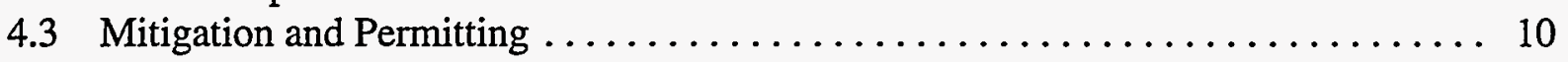

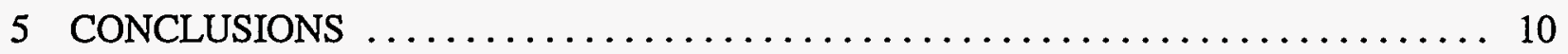

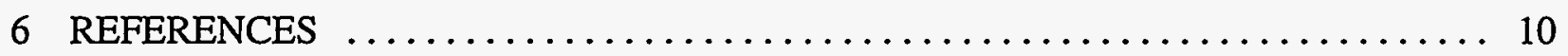




\section{FIGURES}

1 Location of the Southeast Drainage $\ldots \ldots \ldots \ldots \ldots \ldots \ldots \ldots \ldots \ldots \ldots \ldots \ldots \ldots \ldots \ldots \ldots \ldots$

2 Segmentation of the Southeast Drainage for Sampling and Evaluation

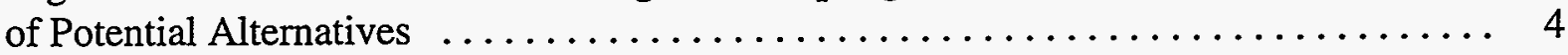

3100 -Year Floodplain of the Southeast Drainage $\ldots \ldots \ldots \ldots \ldots \ldots \ldots \ldots \ldots .6$ 


\title{
FLOODPLAIN/WETLANDS ASSESSMENT FOR THE REMEDIATION OF THE SOUTHEAST DRAINAGE NEAR THE WELDON SPRING SITE, WELDON SPRING, MISSOURI
}

by

R. Van Lonkhuyzen and S.C.L. Yin

\begin{abstract}
The U.S. Department of Energy proposes to remove contaminated sediments from selected portions of the Southeast Drainage, a natural stream near the Weldon Spring site in Missouri. Under the Preferred Alternative, approximately $1,929 \mathrm{~m}^{3}\left(2,551 \mathrm{yd}^{3}\right)$ of sediments would be excavated from the Southeast Drainage. Aquatic communities within the stream would be temporarily disturbed, but populations of aquatic biota within the stream would be expected to recover. No long-term adverse impacts to floodplains are expected.
\end{abstract}

\section{INTRODUCTION}

This floodplain/wetlands assessment has been prepared to support the proposed removal of contaminated sediments from selected portions of the Southeast Drainage as part of cleanup activities being conducted by the U.S. Department of Energy (DOE) at the Weldon Spring site in St. Charles County, Missouri. The Weldon Spring site is located near the town of Weldon Spring, about $48 \mathrm{~km}(30 \mathrm{mi})$ west of St. Louis. It consists of two noncontiguous areas: (1) the chemical plant area and (2) a limestone quarry about $6.4 \mathrm{~km}(4 \mathrm{mi})$ south-southwest of the chemical plant area. The Southeast Drainage, an intermittent tributary of the Missouri River located within the Weldon Spring Conservation Area, is a natural stream $(2.4 \mathrm{~km}$ [1.5 mi] long) that carries surface runoff to the Missouri River from the southern portion of the chemical plant area and a small portion of the U.S. Army Weldon Spring Training Area (Figure 1). The drainage became contaminated as a result of past activities of the U.S. Army and the DOE (and its predecessors).

This floodplain/wetlands assessment evaluates the potential impacts to floodplains and wetlands from the proposed excavation of contaminated sediments from this area. The assessment has been prepared in accordance with Executive Order 11988, Floodplain Management, and Executive Order 11990, Protection of Wetlands, and with DOE guidance and policy (Title 10, Code of Federal Regulations, Part 1022 [10 CFR Part 1022]) for compliance with these Executive Orders. 


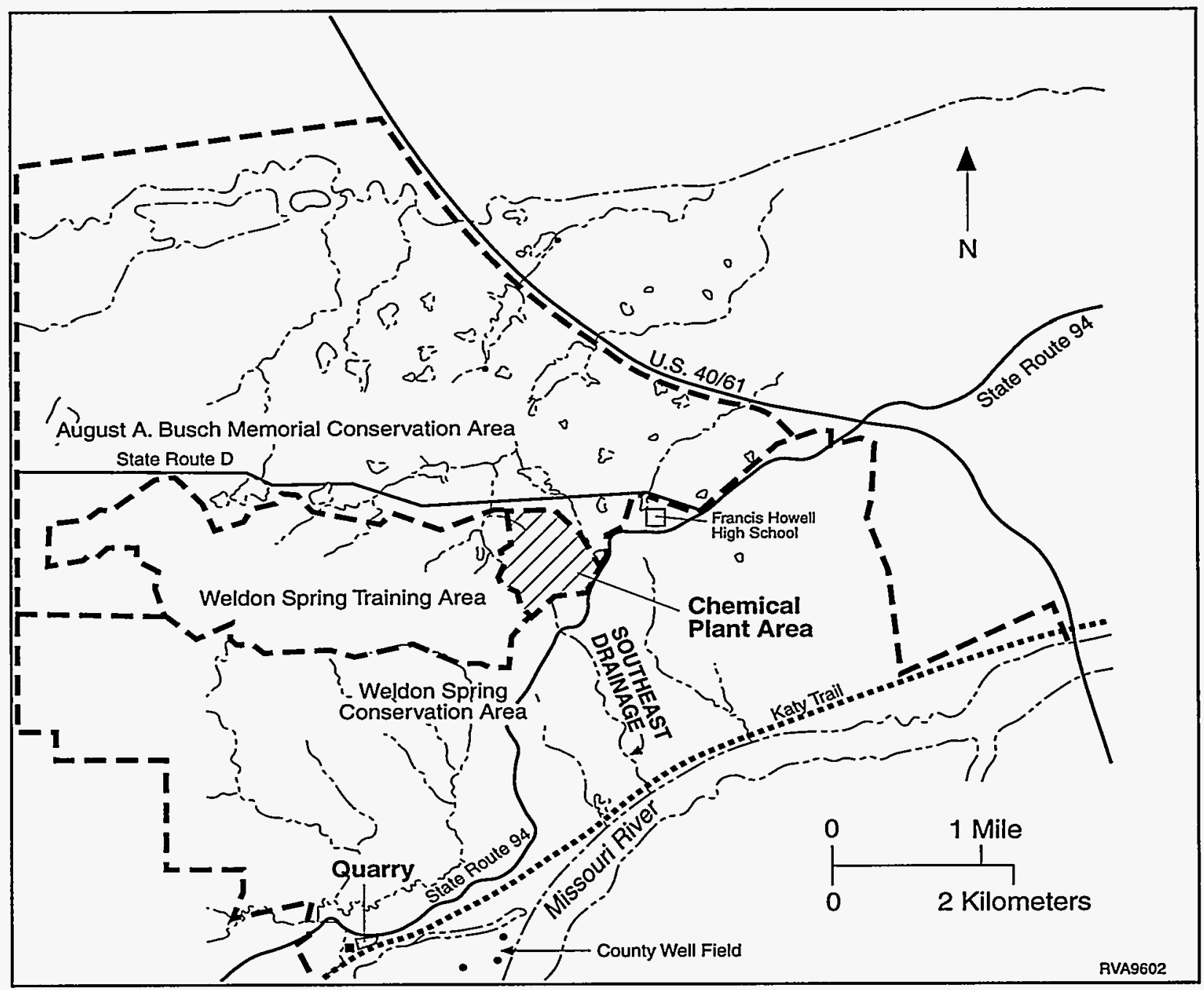

FIGURE 1 Location of the Southeast Drainage

\section{DESCRIPTION OF POTENTIAL ALTERNATIVES}

The DOE is conducting response actions at the Weldon Spring site under its Environmental Restoration and Waste Management Program. The site is listed on the National Priorities List of the U.S. Environmental Protection Agency. Cleanup activities at the Weldon Spring site include the remediation of several scattered sites in the vicinity of the chemical plant and quarry areas, including the Southeast Drainage. The stream channel of the drainage contains sediments that are contaminated with chemicals and radionuclides, including uranium, radium, and thorium. The surface water in the drainage also contains radioactive and chemical contaminants. Two alternatives have been identified for the Southeast Drainage: No Action and Conventional Excavation. These alternatives are evaluated in an Engineering Evaluation/Cost Analysis prepared for the drainage (DOE 1996). 


\subsection{ALTERNATIVE 1: NO ACTION}

Under Alternative 1, No Action, contaminated sediments would be left in place in the Southeast Drainage. No attempt would be made to remove or contain the radioactive contamination or to control access to the area.

\subsection{ALTERNATIVE 2: CONVENTIONAL EXCAVATION}

Alternative 2, Conventional Excavation, would involve the use of conventional excavation technologies to remove contaminated sediments from portions of the Southeast Drainage. The objective of this alternative is to reduce the levels of environmental contamination and thereby reduce potential risks to human health and the environment. Evaluation of alternatives was facilitated by mapping the drainage into four segments: A, B, C, and D (Figure 2). Under Alternative 2, contaminated sediments would be removed by conventional excavation in all four segments. Two subalternatives regarding the areas to be remediated are as follows:

- Subalternative 2.1: Conventional removal of sediments at selected locations within the drainage using existing right-of-way routes and Katy Trail access.

- Subalternative 2.2: Conventional removal of sediments at all targeted locations within the drainage using new off-road access and a haul route through the drainage.

Subalternative 2.1 has been identified as the Preferred Alternative (DOE 1996). Excavation of sediments would generally extend 0.6 to $0.9 \mathrm{~m}$ ( 2 to $3 \mathrm{ft}$ ) below the surface, and approximately $1,929 \mathrm{~m}^{3}\left(2,551 \mathrm{yd}^{3}\right)$ of sediments would be removed. Sediments would be removed from selected locations within all segments of the drainage by tracked excavation equipment and loaded into offroad haul trucks. Selected locations in Segment C, lower Segment B, and portions of Segment A would be accessed with tracked vehicles using existing right-of-way corridors. A temporary haul road would also be constructed within the lower portion of Segment $D$ to facilitate truck access from Katy Trail to the remaining selected removal locations. Construction of the haul road would require minimal grading and removal of trees and other vegetation. Excavated sediments would then be transported to the Ash Pond Storage Area or Material Staging Area in the northwest corner of the chemical plant area. Following sediment removal operations, the temporary access road material would be removed to the chemical plant area. Upon completion of excavation activities, the streambed would be regraded to avoid steep or vertical slopes and to minimize ponding. 


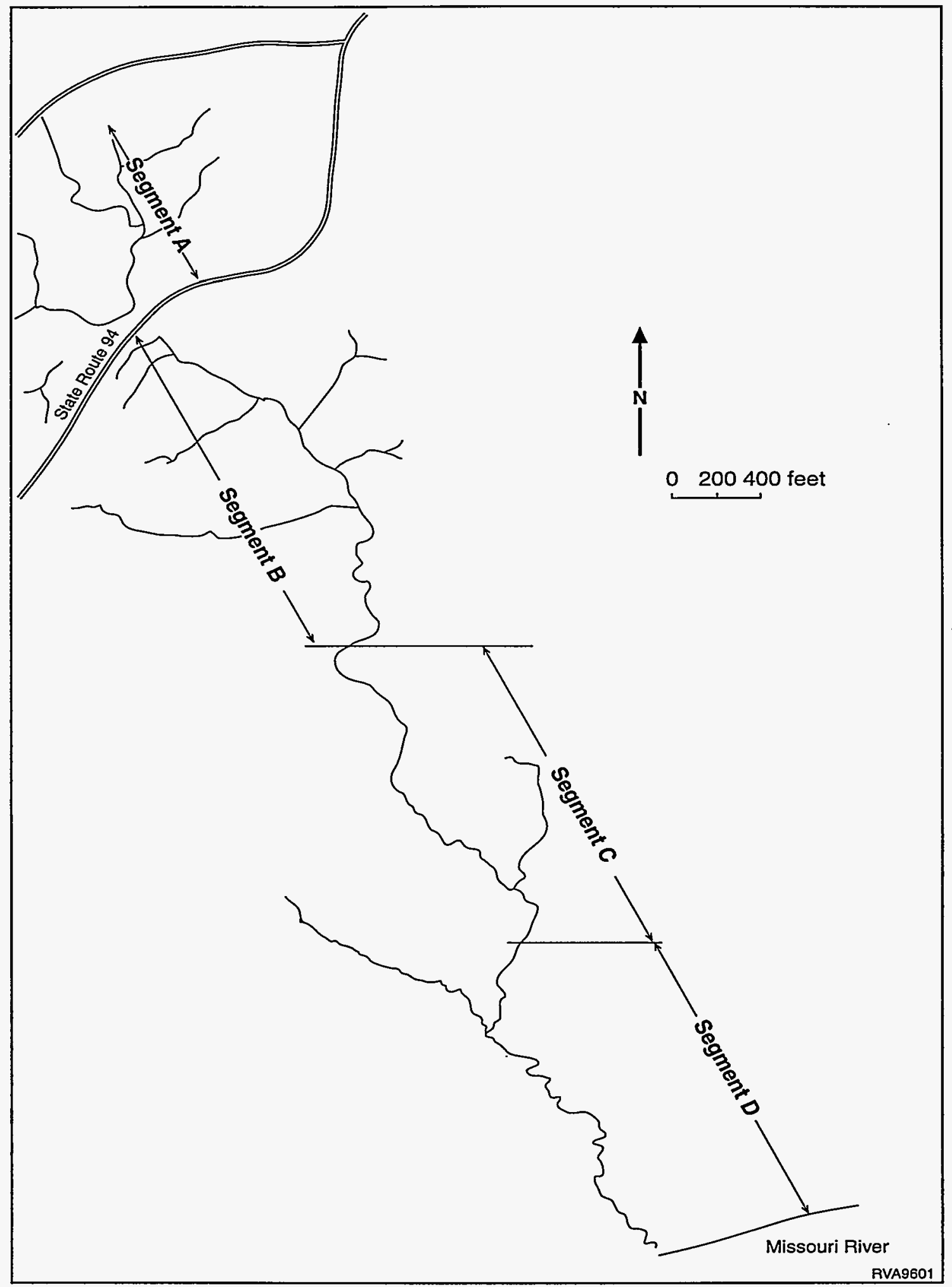

FIGURE 2 Segmentation of the Southeast Drainage for Sampling and Evaluation of Potential Alternatives 
Subalternative 2.2 would also involve removal of sediments from all drainage segments but from more locations than Subalternative 2.1. A new haul route would be constructed through the entire length of the drainage, requiring extensive clearing and tree removal. A temporary off-road access route at the north end of Segment B would provide access from a staging and decontamination area near State Route 94 to Segments B, C, and D. Under Subalternative 2.2, the total volume of sediments removed would be approximately $2,828 \mathrm{~m}^{3}\left(3,703 \mathrm{yd}^{3}\right)$.

\section{DESCRIPTION OF THE FLOODPLAINS AND WETLANDS OF THE SOUTHEAST DRAINAGE}

\subsection{FLOODPLAINS}

Stream flow within the Southeast Drainage results from surface water drainage, groundwater, and four springs that are scattered along the drainage in the channel. Stream flow is seldom continuous within the channel, except after major storm events. Segments of the channel downstream of the springs contain flowing water, but much of the channel is usually dry. The 100 -year floodplain of the Southeast Drainage is shown in Figure 3. Soil of the drainage is mapped as Goss cherty silt loam (Tummons 1982), which is a steep-sloped, well-drained soil on long side slopes. Cedargap soil is included within the Goss unit and occurs along narrow drainageways. This soil is a nearly level, somewhat excessively drained soil that occasionally floods for very brief duration (less than 2 days). The dominant vegetation of the Southeast Drainage floodplain consists of a mature overstory of sugar maple and sycamore, with scattered hackberry, shagbark hickory, cottonwood, and oak. A sapling layer of young pawpaw, with scattered redbud, occurs throughout much of the floodplain. Herbaceous species include wood nettle, clearweed, bellflower, snakeroot, honewort, harbinger-ofspring, false rue anemone, and false Solomon's seal.

The 100-year floodplain of the Missouri River is relatively flat and extends to the base of the escarpment immediately northwest of the Katy Trail and into the Southeast Drainage approximately $370 \mathrm{~m}(1,200 \mathrm{ft}$ ) from the Katy Trail (Federal Emergency Management Agency 1992). The 100-year flood elevation of the Missouri River in the vicinity of the Southeast Drainage is approximately $144 \mathrm{~m}$ (472 ft) above mean sea level. Located within the floodplain is the St. Charles County well field to the southwest of the drainage. A dike (elevation approximately $143 \mathrm{~m}$ [470 ft]) is located upstream along the Missouri River, bordering the county well field and extending northwest along Femme Osage Creek and Little Femme Osage Creek to the Katy Trail. Soil of the Missouri River floodplain in the vicinity of the Southeast Drainage is Hodge loamy fine sand (Tummons 1982), which is a nearly level, somewhat excessively drained soil with frequent flooding for brief to long duration (from 2 to 7 days to more than 7 days). 


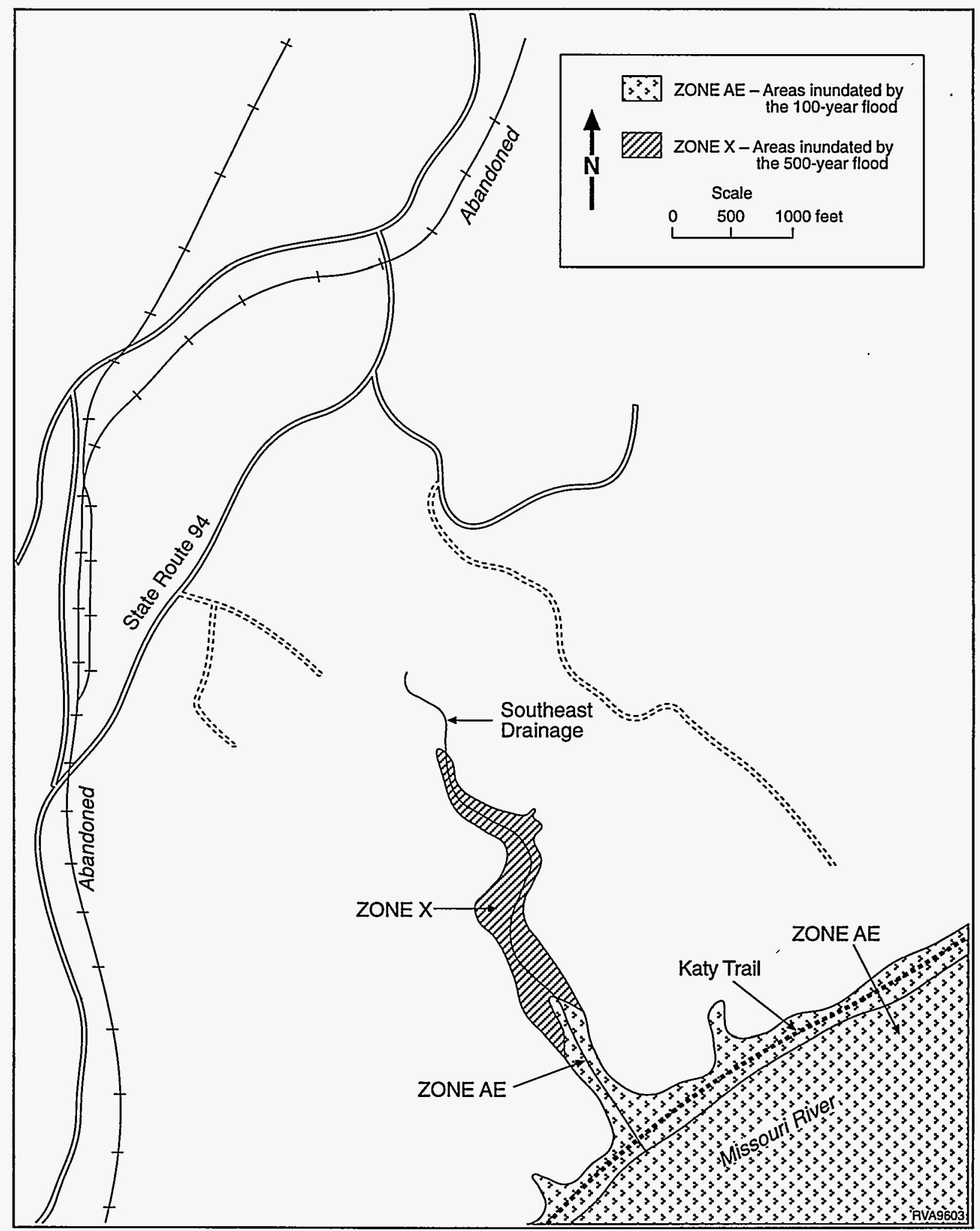

FIGURE 3 100-Year Floodplain of the Southeast Drainage 


\subsection{WETLANDS}

Wetland surveys were conducted in March 1994, March 1995, and August 1995 to determine the presence of jurisdictional wetlands within the Southeast Drainage. For an area to be designated a jurisdictional wetland, current federal guidelines (Environmental Laboratory 1987) require the presence of wetland indicators for three parameters: wetland hydrology, hydric soil, and hydrophytic vegetation. The results of the three surveys indicated that no jurisdictional wetlands are located within the stream channel or floodplain. Sediments of the streambed consist primarily of fractured chert that is reworked during high flows. The channel is unvegetated except for occasional scattered herbaceous plants, such as clearweed or smartweed, on raised gravel bars. The stream cuts a distinct channel through the floodplain, with the bank typically rising abruptly 0.3 to $0.9 \mathrm{~m}$ ( 1 to $3 \mathrm{ft}$ ) above the streambed. Soils along the bank and throughout the floodplain are not inundated or saturated for long enough periods for wetland hydrology criteria to be met. However, the drainage is protected (up to the ordinary high water mark) under Section 404 of the Clean Water Act (Environmental Laboratory 1987) because it is a tributary of the Missouri River and, therefore, is designated a "Water of the United States."

The National Wetlands Inventory does not identify any wetlands within the Southeast Drainage (U.S. Fish and Wildlife Service 1989). The wetland that was mapped nearest to the drainage is the channel of the Missouri River; this channel is classified as a lower perennial riverine wetland with an unconsolidated bottom and is permanently flooded.

Small scattered areas of permanent surface waters, such as the four springs located in the channel or areas of the channel where surface waters occur for extended periods, would be classified as riverine wetlands under the U.S. Fish and Wildlife Service classification system (Cowardin et al. 1979). These areas are unvegetated but support aquatic biota such as macroinvertebrates and, in the lower portion of the stream, fish species, including the green sunfish. Ten amphibian species are known to occur in the Southeast Drainage, including the wood frog (state-listed as rare). The surface waters may provide breeding habitat for amphibian species.

\section{POTENTIAL IMPACTS TO FLOODPLAINS AND WETLANDS}

\subsection{FLOODPLAINS}

\subsubsection{Impacts of the No-Action Alternative}

Alternative 1, the No-Action Alternative, would have no impact on the floodplain of the Southeast Drainage because there would be no disturbance of the stream channel or the floodplain. 
Also, no impacts to the flood storage capacity of the Missouri River 100-year floodplain would be expected under the No-Action Alternative. However, radioactive materials would continue to remain in the sediments and potentially contaminate the surface waters of the floodplain, with the potential for adverse ecological and human health effects.

\subsubsection{Impacts of Subalternative 2.1}

The effect of Subalternative 2.1 on flood elevation during the removal action is expected to be negligible because only negligible encroachment of the flow area would result from the temporary haul road. The access road materials would be removed to the chemical plant area for reuse or disposal after the removal action (DOE 1996). This subalternative would have a negligible long-term effect on the floodplain of the Southeast Drainage once the removal action was complete and the disturbed areas of the floodplain were restored to near preremoval conditions. The final streambed elevation in areas where excavation was conducted would be slightly lower than the current elevation, and this subalternative would have negligible effect on flood elevations. Under Subalternative 2.1, the amount of contaminated sediments in the drainage would be reduced, thus reducing the risk to ecological resources within the floodplain.

No long-term impacts to the 100-year floodplain of the Missouri River would be expected under Subalternative 2.1. A small portion of the floodplain would be temporarily disturbed during cleanup. No permanent structures would be constructed within the floodplain, and final soil surface contours would be similar to the original topography. Thus, no change in flood storage capacity would occur.

\subsubsection{Impacts of Subalternative 2.2}

Similar to Subalternative 2.1, the potential effect of Subalternative 2.2 on flood elevation during the removal action is expected to be negligible because the temporary access road would cause little encroachment of the channel. Subalternative 2.2 would have negligible long-term effects on the floodplain of the Southeast Drainage once the removal action was complete and the disturbed areas of the floodplain were restored to near preremoval conditions. Under Subalternative 2.2, the amount of contaminated sediments in the drainage would be reduced further than under Subalternative 2.1, thus further reducing the risk to ecological resources within the floodplain.

\subsection{WETLANDS}

No jurisdictional wetlands are located within the stream channel or floodplain of the Southeast Drainage. Therefore jurisdictional wetlands would not be impacted by any of the 
alternatives evaluated. However, riverine wetlands (as classified by the U.S. Fish and Wildlife Service) do occur within the drainage, and these could be affected by some of the alternatives.

\subsubsection{Impacts of the No-Action Alternative}

Under Alternative 1, the No-Action Alternative, no disturbance to riverine wetland areas in the Southeast Drainage would occur. However, radioactive materials would continue to remain in the sediments and potentially contaminate the surface waters of riverine wetland areas within the drainage. Potential long-term ecological effects of the contamination would continue.

\subsubsection{Impacts of Subalternative 2.1}

No jurisdictional wetlands would be affected by Subalternative 2.1. However, areas within the Southeast Drainage classified as riverine wetlands under the U.S. Fish and Wildlife Service classification system (Cowardin et al. 1979) would potentially be disturbed during haul road construction, during excavation of sediments, and by increased turbidity during the project and following its completion. Aquatic biota might be eliminated from some areas due to excavation, sedimentation, or disturbance. However, because of the intermittent nature of flow in the drainage, aquatic habitat is limited and the drainage supports a relatively limited aquatic community. Thus, impacts to aquatic biota are expected to be minor. With the implementation of adequate erosioncontrol measures, excess fine sediments would eventually be flushed from the drainage channel. Biota would be expected to recolonize from undisturbed upstream areas following the conclusion of project activities. Thus, no significant long-term adverse impacts to these areas would be expected. Subalternative 2.1 would be expected to result in lower exposures to contaminants for aquatic biota within the Southeast Drainage, thus resulting in a long-term beneficial impact to these riverine wetland areas.

\subsubsection{Impacts of Subalternative 2.2}

Impacts of Subalternative 2.2 would be similar to those of Subalternative 2.1 but with greater areas of disturbance within the drainage channel, including riverine wetland areas. Vegetation removal from steep slopes within the upper segments of the Southeast Drainage would increase the potential for mid- to long-term erosion and would increase turbidity in the stream channel. This increased turbidity could result in longer recovery periods for biota in riverine wetland areas within the Southeast Drainage. Under this subalternative, the amount of contaminated sediments in the Southeast Drainage would be further reduced beyond that of Subalternative 2.1, thus resulting in lower exposures to contaminants and subsequent greater reduction in risk for aquatic biota within the drainage. This risk reduction would result in a greater long-term benefit for riverine wetland areas. 


\subsection{MITIGATION AND PERMITTING}

A storm-water control plan would be developed and implemented during the remediation to minimize sedimentation and erosion impacts to adjacent floodplain areas and surface waters. Mulching and seeding would be used on disturbed upland areas to reduce erosion and sedimentation and ensure the rapid recovery of vegetation. During excavation, airborne dust would be reduced by spraying water on the haul route. All equipment and road surfaces would be decontaminated, as necessary, following completion of project activities. Disturbed areas within the Southeast Drainage floodplain would be regraded and restored to natural conditions to the extent possible. Although no jurisdictional wetlands would be affected by this removal action, a Section 404 permit would be required by the U.S. Army Corps of Engineers.

\section{CONCLUSIONS}

Subalternative 2.1, which has been identified as the Preferred Alternative, would not be expected to result in long-term impacts to the 100-year floodplain of the Southeast Drainage or the Missouri River. The temporary disturbance due to excavation and road construction activities would cease following restoration of the site. Surface waters (classified as riverine wetlands under the U.S. Fish and Wildlife Service classification system) would be temporarily disturbed by the remediation activities, but populations of aquatic biota would be expected to recover.

Subalternative 2.2 would result in greater disturbance to riverine wetlands and potential long-term erosion and sedimentation impacts; however, risk to ecological resources from exposure

to contaminants would be lower. The No-Action Alternative would not disturb floodplains or wetlands, but the risks to ecological resources would continue.

\section{REFERENCES}

Cowardin, L.M., et al, 1979, Classification of Wetlands and Deepwater Habitats of the United States, FWS/OBS-79/31, U.S. Fish and Wildlife Service, Washington, D.C.

DOE: see U.S. Department of Energy.

Environmental Laboratory, 1986, Corps of Engineers Wetlands Delineation Manual, Technical Report Y-87-1, U.S. Army Engineer Waterways Experiment Station, Vicksburg, Miss. 
Federal Emergency Management Agency, 1992, Flood Insurance Rate Map, St. Charles County, Missouri, and Incorporated Areas, Panels 100 and 105, Washington, D.C.

Tummons, R.L., 1982, Soil Survey of St. Charles County, Missouri, U.S. Soil Conservation Service.

U.S. Department of Energy, 1996, Engineering Evaluation/Cost Analysis for the Proposed Removal Action at the Southeast Drainage near the Weldon Spring Site, Weldon Spring, Missouri, DOE/OR/21548-584, prepared by Argonne National Laboratory, Argonne, Ill., for U.S. Department of Energy, Weldon Spring Site Remedial Action Project, Weldon Spring, Mo., Aug.

U.S. Fish and Wildlife Service, 1989, National Wetlands Inventory Map, Weldon Spring, MO, Quadrangle, National Wetlands Inventory, St. Petersburg, Fla. 